\title{
ANALISIS FAKTOR-FAKTOR YANG MEMPENGARUHI TINGKAT PENGANGGURAN DI PROVINSI SUMATERA UTARA TAHUN 1978-2014 DENGAN METODE ORDINARY LEAST SQUARE
}

\author{
Isnayanti, Arnah Ritonga \\ Jurusan Matematika FMIPA UNIMED Medan, Indonesia \\ e-mail: isnayanti30@gmail.com \\ e-mail: arnahritonga@ yahoo.co.id
}

\begin{abstract}
Abstrak
Tujuan dari Penelitian ini adalah untuk menganalisis faktor-faktor yang mempengaruhi tingkat pengangguran di provinsi sumatera utara tahun 1978-2014. Dengan variabel independen jumlah penduduk angkatan kerja, inflasi, pertumbuhan ekonomi, upah minimum dan tingkat pendidikan tamatan menengah atas di provinsi Sumatera Utara sedangkan variabel dependen adalah pengangguran. Data yang digunakan adalah data sekunder dari Badan Pusat Statistik (BPS) Provinsi Sumatera Utara dengan runtun waktu tahun 1978-2014. Langkah-langkah penelitian yang akan dilakukan adalah: Menentukan teori atau hipotesis; Membuat model matematika dan model ekonometrika dari hipotesis yang ada; Mengumpulkan data; Estimasi parameter dari model ekonometrika; Melakukan pengujian hipotesis; dan membuat kesimpulan. Metode analisis yang dipergunakan adalah metode Ordinary Least Square atau metode kuadrat terkecil. Teknik analisis data yang digunakan adalah regresi linear berganda dengan menggunakan program Eviews 7. Hasil penelitian menunjukkan bahwa variabel angkatan kerja berpengaruh positif sebesar 3, 059904\% dan tidak signifikan, inflasi bepengaruh positif sebesar 0, 020060\% dan tidak signifikan, pertumbuhan ekonomi berpengaruh negatif sebesar 3, 105293\% dan signifikan, upah minimum berpengaruh negatif sebesar 1, 003877\% dan signifikan, dan tingkat pendidikan berpengaruh positif sebesar 0, 282733\% dan signifikan terhadap tingkat pengangguran di provinsi sumatera utara tahun 1978-2014. Faktor yang paling dominan mempengaruhi tingkat pengangguran di Provinsi Sumatera Utara tahun 1978 2014 dalam penelitian ini adalah faktor pertumbuhan ekonomi.
\end{abstract}




\title{
Kata kunci: Angkatan Kerja, Inflasi, Metode Ordinary Least Square, Pengangguran, Pertumbuhan Ekonomi, Tingkat Pendidikan, Upah Minimum
}

\begin{abstract}
The purpose of this study was to analyze the factors affecting the level of unemployment in the province of North Sumatra in 1978-2014. With independent variable population of the workforce, inflation, economic growth, minimum wage and the level of upper secondary education graduates in the province of North Sumatra, while the dependent variable is unemployment. The data used are secondary data from the Central Statistics Agency (BPS) of North Sumatra province with time series from 1978 to 2014 year. Research steps to be performed are: Determine the theory or hypothesis; Creating mathematical models and econometric model of hypotheses; Collecting data; Parameter estimation of an econometric model; Test hypotheses; and make conclusions. The analytical method used was Ordinary Least Square method or the method of least squares. Data analysis technique used is multiple linear regression using Eviews program 7. The results showed that the variables of the labor force has positive effect amounting to 3059 $904 \%$ and not significant, positive bepengaruh inflation at $0,020060 \%$ and not significant, negative impact of economic growth $3105293 \%$ and a significant, negative impact of minimum wage amounted to $1,003877 \%$ and a significant and positive influence education levels of $0,282733 \%$ and significant impact on the unemployment rate in the province of north Sumatra in 1978-2014. The most dominant factor affecting the level of unemployment in the province of North Sumatra in 19782014 in this study is a factor of economic growth.
\end{abstract}

Keywords : Labor Force, Inflation, Ordinary Least Square method, Unemployment, Economic Growth, Education Level, Minimum Wage

\section{Pendahuluan}

Pembangunan ekonomi merupakan sebuah proses multidimensi yang melibatkan perubahan-perubahan besar dalam struktur sosial, sikap masyarakat, dan kelembagaan nasional, seperti halnya percepatan ekonomi, pengurangan ketidakmerataan dan pemberantasa kemiskinan absolut. Oleh karenanya, pembangunan ekonomi tidak dapat diukur semata-mata dari tingkat pertumbuhan pendapatan atau pendapatan perkapita, 
namun harus pula melihat bagaimana pendapatan tersebut di distribusikan kepada penduduk dan mengetahui siapa yang mendapat manfaat dari pembangunan tersebut. Pertumbuhan ekonomi belum dapat dikatakan berhasil jika beban sosial semakin berat, pengangguran semakin meningkat, distribusi pendapatan tidak merata dan jumlah penduduk dibawah garis kemiskinan juga semakin meningkat [1].

Tingginya angka pengangguran biasanya disebabkan oleh rendahnya pertumbuhan lapangan pekerjaan yang tersedia ataupun tingginya kriteria rekruitmen penawaran kesempatan kerja yang ada. Saat ini banyak perusahaan yang mencari tenaga kerja dengan pendidikan minimal diploma ataupun sarjana. Keadaan ini membuat sebagian penduduk merasa tidak mampu dan tidak memiliki kesempatan memasuki dunia kerja. Jumlah penduduk yang semakin tinggi juga menjadi salah satu faktor semakin tingginya jumlah pengangguran di Provinsi Sumatera Utara. Berdasarkan data BPS menunjukkan jumlah penduduk provinsi Sumatera Utara yang mengalami kenaikan dari tahun-ketahun. Dimulai pada tahun 2004 sebesar 11.649.655 jiwa sampai pada tahun 2014 sebesar 13.766.851 jiwa [2, 3]. Kenaikan tersebut juga diikuti oleh kenaikan jumlah pengangguran, hal ini menunjukkan kenaikan jumlah penduduk tidak terserap ke lapangan pekerjaan sehingga jumlah pengangguran pun naik.

Permasalahan pengangguran memang sangat kompleks untuk dibahas dan merupakan isu penting, karena dapat dikaitkan dengan beberapa indikator. Indikatorindikator ekonomi yang mempengaruhi tingkat pengangguran antara lain pertumbuhan ekonomi negara yang bersangkutan, tingkat inflasi, serta besaran upah yang berlaku.

Hubungan Pertumbuhan ekonomi dengan Pengangguran dijelaskan oleh Hukum Okun. Teori ini menyatakan bahwa ada hubungan antara pertumbuhan ekonomi (dalam hal ini PDB) dengan pengangguran. Hukum okun menyatakan bahwa setiap adanya peningkatan terhadap persentase pengangguran dalam suatu daerah maka hal tersebut akan setara dengan terjadinya penurunan besarnya PDB riil sebesar 2 persen. Jika terjadi peningkatan output nasional/daerah dalam hal ini pertumbuhan ekonomi maka akan menyebabkan permintaan tenaga kerja naik dan pengangguran turun. Sebaliknya jika PDB riil turun maka akan menyebabkan output yang diproduksi turun. Turunnya produksi mengakibatkan produsen mengurangi kapasitas produksi dan memaksa produsen mengurangi input dalam hal ini tenaga kerja yang akhirnya pengangguran meningkat [4]. 
Indikator ekonomi selanjutnya yang berpengaruh terhadap tingkat pengangguran adalah Inflasi. Inflasi merupakan suatu gejala dimana tingkat harga umum mengalami kenaikan secara terus menerus [5].

A.W. Phillips menggambarkan bagaimana sebaran hubungan antara inflasi dengan tingkat pengangguran didasarkan pada asumsi bahwa inflasi merupakan cerminan dari adanya permintaan agregat. Dengan naiknya permintaan agregat, maka sesuai dengan teori permintaan, jika permintaan naik maka harga akan naik. Dengan tingginya harga (inflasi) maka untuk memenuhi permintaan tersebut produsen meningkatkan kapasitas produksinya dengan menambah tenaga kerja. Akibat dari peningkatan harga-harga (inflasi) maka permintaan tenaga kerja meningkat, dan pengangguran berkurang [6],

Permasalahan utama selanjutnya dan mendasar dalam ketenagakerjaan di Provinsi Sumatera Utara adalah masalah upah yang rendah dan secara langsung dan tidak langsung berpengaruh pada tidak pengangguran yang tinggi. Hal tersebut disebabkan karena pertambahan tenaga kerja barujauh lebih besar dibandingkan dengan pertumbuhan lapangan kerja yang dapat disediakan setiap tahunnya. Menurut Mankiw (2000), upah merupakan salah satu faktor yang mempengaruhi tingkat pengangguran. Selain itu, upah juga merupakan kompensasi yang diterima oleh satu unit tenaga kerja yang berupa jumlah uang yang dibayarkan kepadanya.

Hal yang tidak kalah penting adalah tingkat pendidikan. Faktor pendidikan kemudian memiliki peranan yang penting terhadap pengangguran. Dimana apabila pendidikan suatu masyarakat rendah dapat berakibat pada meningkatnya tingkat pengangguran di negara tersebut. Demikian pula sebaliknya. Hal ini disebabkan karena kurangnya sumber daya manusia yang memiliki pengetahuan, skill dan keahlian.

Pengangguran merupakan salah satu tolak ukur sosio ekonomi dalam menilai keberhasilan pembangunan yang dilakukan pemerintah di suatu daerah. Banya sekali masalah-masalah sosial yang bersifat negatif timbul akibat meningkatnya pengangguran. Pengangguran yang ada di Provinsi Sumatera Utara hingga tahun 2014 menunjukkan jumlah penduduk yang tergolong penganggur masih cukup tinggi yaitu mencapai 6,23\%. Hal tersebut menunjukkan bahwa belum maksimalnya kebijakan pemerintah Sumatera Utara dalam menanggulani masalah pengangguran. Diharapkan faktor - faktor yang mempengaruhi tingkat pengangguran seperti jumlah angkatan kerja, inflasi, pertumbuhan ekonomi, upah dan tingkat pendidikan dapat meminimalisir pengangguran yang terjadi di Provinsi Sumatera Utara. 
Pada tahun 2014, penelitian dilakukan oleh Cita yang berjudul "Analisis Pengaruh Inflasi dan Pertumbuhan Ekonomi Terhadap Pengangguran di Kota Ambon”. Model analisis yang digunakan adalah regresi linier berganda dengan metode OLS. Berdasarkan hasil penelitian, diperoleh kesimpulan bahwa tingkat pengangguran di Kota Ambon dipengaruhi oleh tingkat inflasi, apabila inflasi itu naik sebesar 1\% maka jumlah pengangguran meningkat sebesar $8,925618 \%$. Tingkat pengangguran dan pertumbuhan ekonomi mempunyai hubungan negatif, apabiila pertumbuhan ekonomi itu naik, maka tingkat pengangguran akan turun dan sebaliknya [7].

Pada tahun 2015, penelitian dilakukan oleh Rizka Febiana Putri yang berjudul "Analisis Inflasi, Pertumbuhan Ekonomi dan Upah Terhadap Pengangguran Terdidik di Provinsi Jawa Tengah Tahun 2009-2013”. Metode penelitian yang digunakan adalah metode kuantitatif dengan data panel yang diuji dengan metode analisis regresi doubel log linier dengan Generalized Least Square (GLS). Hasil penelitiannya adalah inflasi, pertumbuhan ekonomi, dan upah secara bersama-sama berpengaruh secara signifikan terhadap pengangguran terdidik di provinsi Jawa Tengah, inflasi berpengaruh negatif dan signifikan sebesar 0.015718 , pertumbuhan ekonomi berpengaruh negatif dan tidak signifikan sebesar -0.04800, upah berpengaruh negatif dan signifikan sebesar -1.488484, [8].

Untuk membatasi ruang lingkup penelitian ini diberikan batasan-batasan, yaitu :

1. Untuk melihat faktor-faktor yang mempengaruhi tingkat pengangguran di Provinsi Sumatera Utara selama kurun waktu 1978-2014 (37 tahun) dengan menggunakan metode OLS (Ordinary Least Square).

2. Pengangguran yang digunakan adalah tingkat pengangguran terbuka

3. Jumlah angkatan kerja yang digunakan dalam penelitian ini adalah jumlah penduduk usia kerja yang bekerja dan tidak bekerja atau sedang mencari pekerjaan

4. Inflasi yang digunakan adalah tingkat inflasi yang menunjukkan besarnya perubahan kumulatif harga-harga secara umum dengan indikator IHK (Indeks Harga Konsumen).

5. Pertumbuhan ekonomi diukur dengan menggunakan Pendapatan Domestik Regional Bruto (PDRB) atas dasar harga konstan 2000 menurut lapangan usaha.

6. Besaran upah yang digunakan adalah upah rata-rata minimum propinsi yang ada di provinsi sumatera utara. 
7. Pendidikan yang digunakan adalah tingkat pendidikan tamatan menengah atas di provi nsi sumatera utara.

Tulisan ini yang merupakan hasil Penelitian bertujuan untuk menganalisis seberapa besar pengaruh faktor angkatan kerja, inflasi, pertumbuhan ekonomi, upah minimum dan tingkat pendidikan terhadap tingkat pengangguran di Provinsi Sumatera Utara tahun 1978-2014. Serta Untuk mengetahui faktor yang paling dominan mempengaruhi tingkat pengangguran di Provinsi Sumatera Utara tahun 1978-2014.

\section{Metode Penelitian}

\section{Jenis Penelitian}

Penelitian ini termasuk dalam penelitian kuantitatif deskriptif karena penelitian ini lebih berdasarkan data yang dapat dihitung untuk menghasilkan penaksiran kuantitatif yang kokoh. Dimana hasil data tersebut akan diuraikan sifat atau karakteristik suatu fenomena tertentu sehingga mencapai suatu kesimpulan yang dibutuhkan.

\section{Data dan Sumber Data}

Data yang digunakan dalam penelitian ini adalah data sekunder yang diperoleh dari publikasi Badan Pusat Statistik yaitu Sumatera Utara dalam angka, tingkat pengangguran terbuka, angkatan kerja, inflasi, PDRB atas dasar harga konstan 2000 menurut lapangan usaha, upah minimum dan tingkat pendidikan tamatan menengah atas provinsi Sumatera Utara. Data yang digunakan bersifat tahunan dan berdasarkan urutan waktu (time series) meliputi kurun waktu 1978-2014.

\section{Teknik Pengumpulan Data}

Metode pengumpulan data yang digunakan penulis dalam penelitian ini adalah metode kepustakaan dan dokumentasi diambil dari dokumen-dokumen yang telah diterbitkan dan dipublikasikan oleh instansi terkait.

\section{Prosedur Penelitian}

Dalam menyajikan tulisan ini penulis menyusun suatu kerangka pemikiran yang berdasarkan langkah-langkah sebagai berikut: 


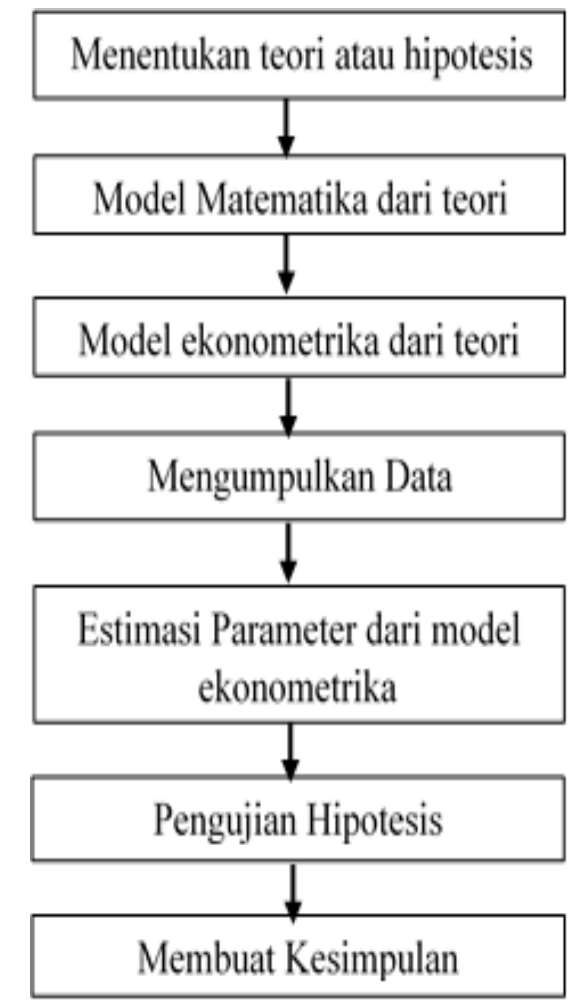

Gambar 1. Flow Chart Prosedur Penelitian

\section{Teknik Analisis Data}

Alat analisis yang penulis gunakan adalah regresi linier berganda dengan menggunakan softwere Eview 7. Analisis faktor-faktor yang mempengaruhi tingkat pengangguran di Provinsi Sumatera Utara tahun 1978-2014 menggunakan metode kuadrat terkecil (OLS) yang bertujuan untuk mengetahui seberapa besar pengaruh angkatan kerja, inflasi, pertumbuhan ekonomi, upah minimum dan tingkat pendidian terhadap tingkat pengangguran di provinsi Sumatera Utara.

Secara ekonometrika hubungan antara jumlah penduduk angkatan kerja, Inflasi, pertumbuhan ekonomi, upah minimum dan tingkat pengangguran terhadap tingkat pengangguran di Provinsi Sumatera Utara tahun 1978-2014 dapat dianalisis dengan menggunakan persamaan berikut :

$Y_{t}=\beta_{0}+\beta_{1} X_{1 t}+\beta_{2} X_{2 t}+\beta_{3} X_{3 t}+\beta_{4} X_{4 t}+\beta_{5} X_{5 t}+u_{t}$

Dimana

$\mathrm{Y}=$ Tingkat Pengangguran Terbuka (Persen)

$\mathrm{X}_{1}=$ Jumlah penduduk Angkatan Kerja (Jiwa) 
$\mathrm{X}_{2}=$ Inflasi (Persen)

$\mathrm{X}_{3}=$ Pertumbuhan Ekonomi (Milyar Rupiah)

X4 = Upah Minimum (Rupiah)

X5 = Tingkat Pendidikan (Persen)

$\beta_{0}=$ Bilangan Konstanta

$\beta_{1}=$ Koefisien jumlah angkatan kerja

$\beta_{2}=$ Koefisien regresi Inflasi

$\beta_{3}=$ Koefisien regresi Pertumbuhan ekonomi

$\beta_{4}=$ Koefisien regresi Upah Minimum

$\beta_{5}=$ Koefisien regresi Tingkat Pendidikan

Sehingga persamaan regresi penduga $\widehat{Y}$ dari suatu pengamatan atau untuk pengaruh variabel independen $(\mathrm{X})$ terhadap variabel dependen $(\mathrm{Y})$ menjadi :

$$
\tilde{Y}=\widetilde{\beta_{0}}+\widetilde{\beta_{1}} X_{1 t}+\widetilde{\beta_{2}} X_{2 t}+\widetilde{\beta_{3}} X_{3 t}+\widetilde{\beta_{4} X_{4 t}}+\widetilde{\beta_{5} X_{5 t}}+\widehat{u_{t}}
$$

\section{Hasil Penelitian}

Sebelum mengetahui keterkaitan antar variabel dalam penelitian ini, berikut merupakan gambaran umum variabel-variabel yang digunakan dalam penelitian. 


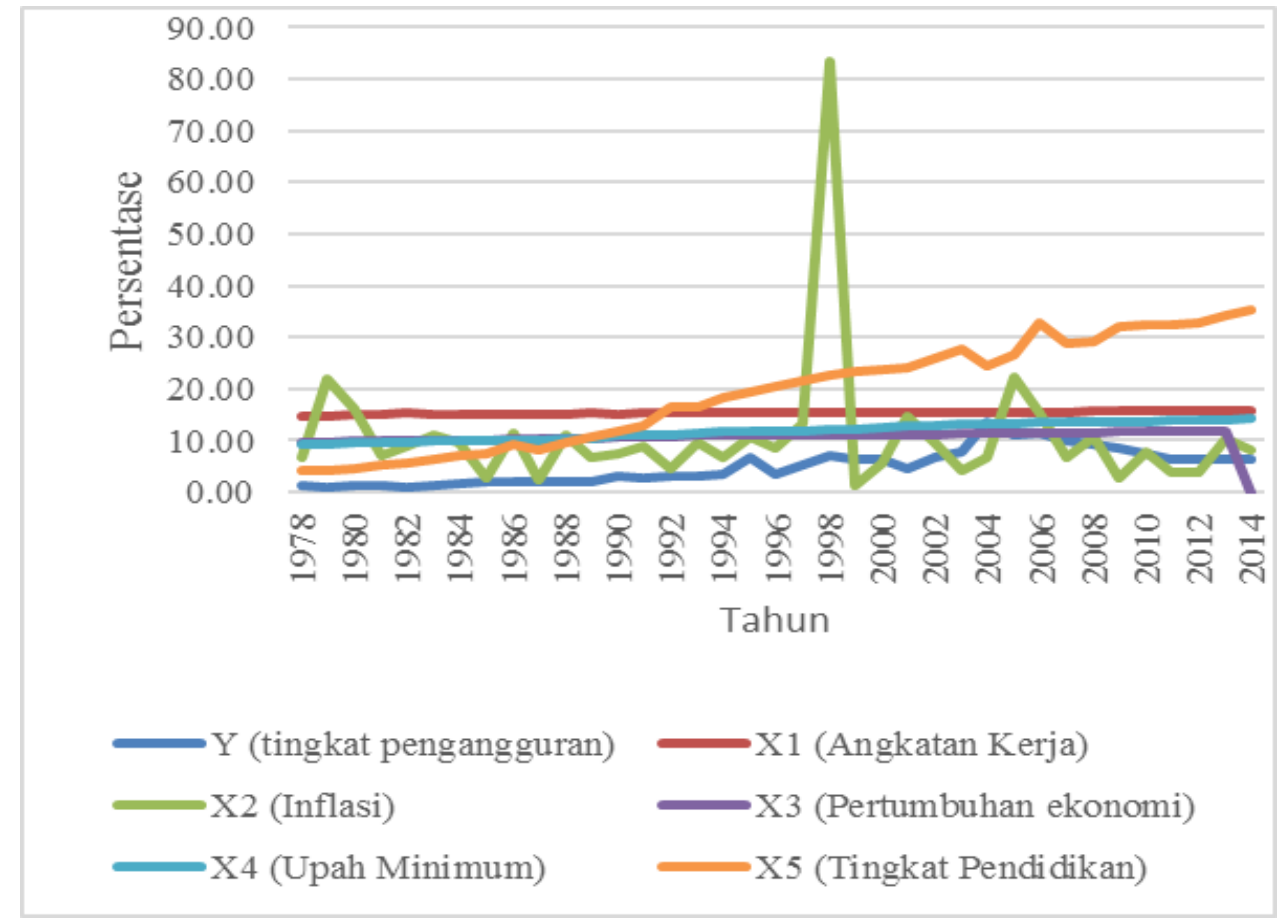

Gambar 2. Perkembangan gambaran umum

tingkat pengangguran, angkatan kerja, inflasi, upah minimum dan tingkat pendidikan di Sumatera Utara tahun 1978-2014.

\section{Analisis Data}

\section{Uji Asumsi Klasik}

\section{Uji Multikolinearitas}

Penelitian ini menggunakan indikator pengujian regresi parsial (auxiliary regression) untuk mendeteksi multikolinearitas dengan metode klein yaitu dengan membandingkan $R^{2}$ auxiliary regression dengan $R^{2}$ pada model utama. Berdasarkan hasil pengujian auxiliary regression diperoleh bahwa terdapat nilai $R^{2}$ auxiliary pada variabel independen $X_{1}, X_{3}, X_{4}$ dan $X_{5}$ yang lebih besar dari nilai $R^{2}$ model utama sehingga dapat disimpulkan bahwa terdapat gejala multikolinearitas pada model penelitian. Oleh karena itu dalam hal ini, peneliti menggunakan cara transformasi variabel dengan melakukan diferensi [9]. 
Dikarenakan setelah dianalisis ternyata ada gangguan multikolinearitas yang tinggi antara angkatan kerja $\left(X_{1}\right)$, pertumbuhan ekonomi $\left(X_{3}\right)$ dan upah minimum $\left(X_{4}\right)$ pada data ini, seiring berjalannya waktu ketiga variabel ini cenderung bergerak ke arah yang sama setiap tahunnya.

Tabel 1. Transormasi Variabel Regresi Auxiliary

\begin{tabular}{|c|c|c|}
\hline Regresi & $R^{2 *}$ & $R^{2}$ \\
\hline$D\left(X_{1}\right)=f\left(X_{2}, D\left(X_{3}\right), D\left(X_{4}\right), X_{5}\right)$ & 0,251503 & 0,709456 \\
\hline$X_{2}=f\left(D\left(X_{1}\right), D\left(X_{3}\right), D\left(X_{4}\right), X_{5}\right)$ & 0,035338 & 0,709456 \\
\hline$D\left(X_{3}\right)=f\left(D\left(X_{1}\right), X_{2}, D\left(X_{4}\right), X_{5}\right)$ & 0,033829 & 0,709456 \\
\hline$D\left(X_{4}\right)=f\left(D\left(X_{1}\right), X_{2}, D\left(X_{3}\right), X_{5}\right)$ & 0,204140 & 0,709456 \\
\hline$X_{5}=f\left(D\left(X_{1}\right), X_{2}, D\left(X_{3}\right), D\left(X_{4}\right)\right)$ & 0,064423 & 0,709456 \\
\hline
\end{tabular}

Sumber : olah data Eviews 7

Berdasarkan tabel 1 diatas, hasil pengujian regresi parsial (auxiliary regression) diperoleh bahwa terdapat nilai auxiliary yang lebih kecil dari nilai $R^{2}$ model utama sehingga dapat disimpulkan bahwa tidak terjadi multikolinearitas pada model penelitian.

\section{Uji Heteroskedastisitas}

Hasil analisis data bebas uji heteroskedastisitas apabila nilai probabilitas obs*Rsquared $>0,05$. Dari hasil analisis menunjukkan bahwa nilai $O b s * R$-squared $=8.318464$ dengan $\mathrm{p}$-value $=0.1395$ Karena $\mathrm{p}$ - value $=0.1395>0,05$ maka $\mathrm{H}_{0}$ ditolak, sehingga dapat disimpulkan bahwa tidak ada heteroskedastisitas dalam model.

\section{Uji Autokorelasi}

Hasil analisis data bebas autokorelasi apabila nilai probability Chi-Square > 0,05 Dari hasil analisis menunjukkan bahwa nilai probability nilai LM Test sebesar $1,0000>0,05$ sehingga dapat disimpulkan tidak ada autokorelasi dalam model penelitian ini.

\section{Uji Normalitas}

Uji normalitas yang digunakan pada penelitian ini menggunakan teknik Jarque-Berra. Apabila nilai probability > 0,05 maka data berdistribusi normal [10]. Dari hasil analisis 
menunjukkan bahwa nilai probability yakni 0,429661 >0,05 maka dapat disimpulkan bahwa data yang digunakan berdistribusi normal.

\section{Uji Linearitas}

Uji linearitas yang digunakan dalam penelitian ini adalah metode Ramsey Rese. Apabila nilai Prob. $F$-hitung > 0,05 maka $H_{0}$ diterima berarti model regresi linier, (Wing, 2015). Dari hasil analisis menunjukkan bahwa prob. F hitung $=0,6426>0,05$ berarti bahwa regresi model yang diuji adalah linear.

\section{Uji Kesesuaian (Test Of Goodness Of Fit)}

Uji Kesesuaian (Test Of Goodness Of Fit) diperlukan untuk mengetahui apakah model regresi yang teristimasi cukup baik atau tidak. Pengujian statistik akan dilakukan dengan menganalisis:

\section{Uji Koefisien Determinasi $\left(R^{2}\right)$}

Dari hasil pengolahan data diperoleh koefisien determinasi $\left(R^{2}\right)$ sebesar 0,7094 . Hal ini menggambarkan bahwa variabel bebas angkatan kerja $\left(X_{1}\right)$, inflasi $\left(X_{2}\right)$, pertumbuhan ekonomi $\left(X_{3}\right)$, upah minimum $\left(X_{4}\right)$ dan tingkat pendidikan $\left(X_{5}\right)$ yang diduga sebagai faktor-faktor yang berpengaruh terhadap variabel terikat yaitu tingkat pengangguran mampu menjelaskan variasi tingkat pengangguran di Provinsi Sumatera Utara sebesar $70,94 \%$ sedangkan sisanya sebesar $29,06 \%$ dijelaskan oleh faktor-faktor lain yang tidak masuk dalam model ini (yang tidak diteliti).

\section{Uji t- statistik}

Pengujian secara parsial dilakukan dengan menggunakan uji t statistik satu sisi terhadap masing-masing variabel independen, dari pengujian regresi didapat nialai $\mathrm{t}$ hitung dari masing-masing variabel untuk selanjutnya dibandingkan dengan nilai t tabel. Dari hasil analisis uji t diperoleh:

Tabel 2. Hasil uji t-statistik

\begin{tabular}{|c|c|c|c|c|c|}
\hline Variabel & $t_{\text {hitung }}$ & $t_{\text {tabel }}$ & Probabilitas & Keterangan & Kesimpulan \\
\hline$X_{1}$ & 0,510758 & 1,69726 & 0,6133 & $t_{\text {hitung }}<t_{\text {tabel }}$ & Positif (tidak signifikan) \\
\hline$X_{2}$ & 0,797345 & 1,69726 & 0,4315 & $t_{\text {hitung }}<t_{\text {tabel }}$ & Positif (tidak signifikan) \\
\hline$X_{3}$ & $-1,663437$ & 1,69726 & 0,1066 & $t_{\text {hitung }}<t_{\text {tabel }}$ & negatif (signifikan) \\
\hline$X_{4}$ & $-0,321667$ & 1,69726 & 0,7499 & $t_{\text {hitung }}<t_{\text {tabel }}$ & negatif (signifikan) \\
\hline$X_{5}$ & 8,399016 & 1,69726 & 0,0000 & $t_{\text {hitung }}>t_{\text {tabel }}$ & positif (signifikan) \\
\hline
\end{tabular}




\section{Sumber : olah data eviews 7}

\section{Uji Signifikansi Simultan (Uji F-statistik)}

Uji F-statistik dilakukan untuk mengetahui apakah variabel independen angkatan kerja $\left(X_{1}\right)$, inflasi $\left(X_{2}\right)$, pertumbuhan ekonomi $\left(X_{3}\right)$, upah minimum $\left(X_{4}\right)$ dan tingkat pendidikan $\left(X_{5}\right)$ secara serempak mempengaruhi variabel dependen tingkat pengangguran $(Y)$.

Berdasarkan hasil uji F-statistik diperoleh bahwa F statistik > F tabel yaitu 14,65 > 2,53 berarti $H_{0}$ ditolak. Dengan demikian, dapat disimpulkan bahwa variabel independen jumlah angkatan kerja $\left(X_{1}\right)$, inflasi $\left(X_{2}\right)$, pertumbuhan ekonomi $\left(X_{3}\right)$, upah minimum $\left(X_{4}\right)$ dan pendidikan $\left(X_{5}\right)$ secara simultan berpengaruh nyata (signifikan) terhadap variabel dependen tingkat pengangguran $(Y)$ pada tingkat keyakinan 95\% $(\alpha=5 \%)$.

\section{Analisis Regresi}

Berdasarkan pengolahan data eviews 7 :

Tabel 3. Hasil Output Regresi

\begin{tabular}{|c|c|c|c|c|}
\hline Variable & Coefficient & Std. Error & t-Statistic & Prob. \\
\hline $\begin{array}{l}D_{(X 1)}^{C} \\
\times 2 \\
D(X 3) \\
D(X 4) \\
X 5\end{array}$ & $\begin{array}{r}-0.281469 \\
3.059904 \\
0.020060 \\
-3.105293 \\
-1.003877 \\
0.282733\end{array}$ & $\begin{array}{l}0.952006 \\
5.990914 \\
0.025158 \\
1.866793 \\
3.120859 \\
0.033663\end{array}$ & $\begin{array}{r}-0.295659 \\
0.510758 \\
0.797345 \\
-1.663437 \\
-0.321667 \\
8.399016\end{array}$ & $\begin{array}{l}0.7695 \\
0.6133 \\
0.4315 \\
0.1066 \\
0.7499 \\
0.0000\end{array}$ \\
\hline $\begin{array}{l}\text { R-squared } \\
\text { S.D. dependent var } \\
\text { Alcaike info criterion } \\
\text { Schrvarz criterion } \\
\text { Hannan-Quinn }\end{array}$ & $\begin{array}{l}0.709456 \\
3.351296 \\
4.325735 \\
4.589655\end{array}$ & \multicolumn{2}{|c|}{$\begin{array}{l}\text { Mean dependent var } \\
\text { S.E. of regression } \\
\text { Sum squared resid } \\
\text { Log likelihood }\end{array}$} & $\begin{array}{r}5.116667 \\
1.951158 \\
114.2105 \\
-71.86322\end{array}$ \\
\hline $\begin{array}{l}\text { criter. } \\
\text { Durbin-W atson stat }\end{array}$ & $\begin{array}{l}4.417850 \\
0.976219\end{array}$ & \multicolumn{2}{|l|}{ F-statistic } & 14.65089 \\
\hline
\end{tabular}


Tabel 4. Persamaan Hasil Estimasi

\section{Estimation Command:}

LS Y C D(X1)X2 D(X3) D(X4) X5

Estimation Equation:

$\mathrm{Y}=\mathrm{C}(1)+\mathrm{C}(2)^{*} \mathrm{D}(\mathrm{X} 1)+\mathrm{C}(3)^{*} \mathrm{X} 2+\mathrm{C}(4)^{*} \mathrm{D}(\mathrm{X} 3)+\mathrm{C}(5)^{*} \mathrm{D}(\mathrm{X} 4)+\mathrm{C}(6)^{*} \mathrm{X} 5$

Substituted Coefficients:

$\mathrm{Y}=-0.28146884561+3.05990428621^{*} \mathrm{D}(\mathrm{X} 1)+0.0200598121069^{*} \mathrm{X} 2$. $3.10529340348^{*} \mathrm{D}(\mathrm{X} 3)-1.00387658881^{*} \mathrm{D}(\mathrm{X} 4)+0.282732950551^{*} \mathrm{X} 5$

Sumber : olah data Eviews 7

Persamaan Estimasi linear regresi berganda antara angkatan kerja $\left(\mathrm{X}_{1}\right)$, inflasi $\left(\mathrm{X}_{2}\right)$, pertumbuhan ekonomi $\left(\mathrm{X}_{3}\right)$, upah minimum $\left(\mathrm{X}_{4}\right)$ dan pendidikan $\left(\mathrm{X}_{5}\right)$ terhadap tingkat pengangguran (Y) Provinsi Sumatera Utara periode 1978-2014 adalah:

$$
\begin{aligned}
\hat{\mathrm{Y}}_{\mathrm{t}}=- & 0,281469+3,059904\left(\mathrm{X}_{1 \mathrm{t}}-\mathrm{X}_{1, \mathrm{t}-1}\right)+ \\
& 0,020060 \mathrm{X}_{2 \mathrm{t}}-3,105293\left(\mathrm{X}_{3 \mathrm{t}}-\mathrm{X}_{3, \mathrm{t}-1}\right)-1,003877\left(\mathrm{X}_{4 \mathrm{t}}-\mathrm{X}_{4, \mathrm{t}-1}\right)+0,282733 \mathrm{X}_{5 \mathrm{t}}
\end{aligned}
$$

\section{Interpretasi model}

Berdasarkan hasil regresi, maka dapat diinterpretasikan sebagai berikut :

1. Koefisien $X_{1}$ adalah positif, artinya ada pengaruh positif antara $X_{1}$ dan Y. Ketika jumlah angkatan kerja $\left(X_{1}\right)$ mengalami kenaikan $1 \%$ maka akan menyebabkan kenaikan tingkat pengangguran (Y) sebesar 3,059904\%.

2. Koefisien $X_{2}$ adalah positif, artinya ada pengaruh positif antara $\left(X_{2}\right)$ dan $Y$. Ketika inflasi $X_{2}$ mengalami kenaikan $1 \%$ maka akan menyebabkan kenaikan tingkat pengangguran (Y) sebesar 0,020060\%.

3. Koefisien $X_{3}$ adalah negatif, artinya ada pengaruh negatif antara $X_{3}$ dan Y. Ketika pertumbuhan ekonomi $\left(X_{3}\right)$ mengalami mengalami kenaikan $1 \%$ maka akan menyebabkan menurunnya tingkat pengangguran (Y) sebesar 3,105293\%.

4. Koefisien $X_{4}$ adalah negatif, artinya ada pengaruh negatif antara $X_{4}$ dan Y. Ketika upah minimum $\left(X_{4}\right)$ mengalami kenaikan $1 \%$ maka akan menyebabkan menurunnya tingkat pengangguran (Y) sebesar 1,003877\%. 
5. Koefisien $X_{5}$ adalah positif, artinya ada pengaruh positif antara $X_{5}$ dan Y. Ketika tingkat pendidikan $\left(X_{5}\right)$ mengalami kenaikan $1 \%$ maka akan menyebabkan kenaikan tingkat pengangguran (Y) sebesar 0,282733\%.

\section{Pembahasan}

Dari hasil analisis data diperoleh bahwa :

\section{Pengaruh Angkatan Kerja Terhadap Tingkat Pengangguran}

Dengan nilai thitung sebesar 0,510758 dan tabel sebesar 1,69726 pada $\alpha=5 \%$ dengan melakukan pengujian satu sisi berarti nilai thitung < ttabel artinya bahwa variabel angkatan kerja secara parsial tidak signifikan mempengaruhi tingkat pengangguran di provinsi sumatera utara tahun 1978-2014 dengan nilai koefisien sebesar 3,059904 yang artinya bahwa terdapat hubungan positif antara angkatan kerja terhadap tingkat pengangguran yaitu ketika jumlah angkatan kerja mengalami kenaikan $1 \%$ maka akan menyebabkan kenaikan tingkat pengangguran sebesar 3, 059904\%. Hal ini adalah sudah sesuai dengan teori yang ada, yaitu semakin meningkatnya angkatan kerja maka semakin meningkat juga tingkat pengangguran. Kenaikan jumlah angkatan kerja tersebut, tidak dibarengi oleh meningkatnya kesempatan kerja, akibatnya angkatan kerja yang jumlahnya bertambah tersebut, tidak dapat didistribusikan ke lapangan pekerjaan. Hal ini akan berdampak pada jumlah pengangguran yang terus bertambah.

\section{Pengaruh Inflasi Terhadap Tingkat Pengangguran}

Dengan nilai thitung sebesar $=0,797345$ dan tabel sebesar 1,69726 pada $\alpha=5 \%$ dengan melakukan pengujian satu sisi berarti nilai thitung $<t_{\text {tabel }}$ artinya bahwa variabel inflasi secara parsial tidak signifikan mempengaruhi tingkat pengangguran di provinsi sumatera utara tahun 1978-2014 dengan nilai koefisien sebesar 0,020060 yang artinya bahwa terdapat hubungan positif antara inflasi terhadap tingkat pengangguran yaitu ketika inflasi mengalami kenaikan 1\% maka akan menyebabkan kenaikan tingkat pengangguran sebesar $0,020060 \%$. Dalam penelitian ini, diperoleh hubungan positif antara inflasi dan tingkat pengangguran. Hal ini dikarenakan tingkat inflasi yang dihitung adalah inflasi yang terjadi pada harga-harga secara umum, maka tingginya tingkat inflasi yang terjadi akan berakibat pada peningkatan tingkat bunga 
(pinjaman).Oleh karena itu, dengan tingkat bunga yang tinggi akan mengurangi investasi untuk mengembangkan sektor-sektor yang produktif .

\section{Pengaruh Pertumbuhan Ekonomi terhadap Tingkat Pengangguran}

Dengan thitung sebesar $=-1,663437$ dan tabel sebesar 1,69726 pada $\alpha=5 \%$ dengan melakukan pengujian satu sisi berarti nilai thitung $<$ tabel artinya bahwa variabel pertumbuhan ekonomi secara parsial signifikan mempengaruhi tingkat pengangguran di provinsi sumatera utara tahun 1978-2014 dengan nilai koefisien sebesar $-3,105293$ yang artinya bahwa terdapat hubungan negatif antara pertumbuhan ekonomi terhadap tingkat pengangguran yaitu ketika pertumbuhan ekonomi mengalami kenaikan 1\% maka akan menyebabkan menurunnya tingkat pengangguran sebesar $3,105293 \%$. Hal ini sesuai dengan teori hukum okun yang menyatakan bahwa terdapat hubungan negatif antara pertumbuhan ekonomi dengan pengangguran. Hukum okun menyatakan bahwa tingkat pengangguran 1 persen setiap ada kenaikan PDB riil 2 persen. Jika terjadi peningkatan output nasional/daerah dalam hal ini pertumbuhan ekonomi maka akan menyebabkan permintaan tenaga kerja naik dan pengangguran turun [4].

\section{Pengaruh Upah Minimum Terhadap Tingkat Pengangguran}

Dengan nilai thitung sebesar $=-0,321667$ dan $t_{\text {tabel }}$ sebesar 1,69726 pada $\alpha=5 \%$ dengan melakukan pengujian satu sisi berarti nilai thitung $<$ tabel artinya bahwa variabel upah minimum $\left(X_{4}\right)$ secara parsial signifikan mempengaruhi tingkat pengangguran di provinsi sumatera utara tahun 1978-2014 dengan nilai koefisien sebesar -1,003877 yang artinya bahwa terdapat hubungan negatif antara upah minimum terhadap tingkat pengangguran yaitu ketika upah minimum mengalami kenaikan $1 \%$ maka akan mengakibatkan menurunnya tingkat pengangguran sebesar 2,003877\%. Hal ini tidak sesuai dengan teori kekakuan upah, dimana Upah tidak selalu bisa fleksibel atau tidak bisa melakukan penyesuaian sampai penawaran tenaga kerja sama dengan permintaannya. Hal ini berarti nilai dari upah minimum ini selalu berada diatas keseimbangan pasar tenaga kerja. Pada dasarnya tuntutan kenaikan upah Minimum Provinsi (UMP) pada tiap provinsi setiap tahunnya yang dilihat dari PDRB nya yang dimaksudkan untuk meningkatkan taraf kesejahteraan kaum buruh, tetapi hal itu berdampak pada berpengaruh negatif terhadap penyerapan tenaga kerja. 


\section{Pengaruh Pendidikan Terhadap Tingkat Pengangguran}

Dengan nilai thitung sebesar 8,399016 dan tabel sebesar 1,69726 pada $\alpha=5 \%$ dengan melakukan pengujian satu sisi berarti nilai thitung $>$ tabel artinya bahwa variabel pendidikan $\left(X_{5}\right)$ secara parsial signifikan mempengaruhi tingkat pengangguran di provinsi sumatera utara tahun 1978-2014 dengan nilai koefisien sebesar 0,282733 yang artinya bahwa terdapat hubungan positif antara pendidikan terhadap tingkat pengangguran yaitu dalam hal ini ketika tingkat pendidikan tamatan menengah atas mengalami kenaikan $1 \%$ maka akan menyebabkan kenaikan tingkat pengangguran sebesar $0,282733 \%$. Hal ini tidak sesuai dengan teori yang ada bahwa semakin tinggi tingkat pendidikan yang diperoleh oleh tenaga kerja maka semakin besar pula tingkat output yang dihasilkan sehingga akan mengurangi pengangguran. Adanya modal manusia berupa tingkat pendidikan yang lebih tinggi akan memberikan efisiensi dan efektifitas dalam berproduksi dan memberikan kesempatan kerja bagi tenaga kerja yang berkualitas dalam mengisi kesempatan kerja di lapangan kerja yang sesuai lulusan atau tamatannya [11]..

\section{Kesimpulan Dan Saran}

\section{Kesimpulan}

Berdasarkan hasil penelitian mengenai faktor-faktor yang mempengaruhi tingkat pengangguran di Provinsi Sumatera utara tahun 1978-2014, maka peneliti dapat mengambil beberapa kesimpulan sebagai berikut:

1. Angkatan kerha berpengaruh positif dan tidak signifikan terhadap tingkat pengangguran dii sumatera utara tahun 1978-2014 yaitu ketika jumlah angkatan kerja mengalami kenaikan 1\% maka akan menyebabkan kenaikan tingkat pengangguran sebesar 3,059904\%.

2. Inflasi berpengaruh positif dan tidak signifikan terhadap tingkat pengangguran di Sumatera utara tahun 1978-2014 yaitu ketika inflasi mengalami kenaikan 1\% maka akan menyebabkan kenaikan tingkat pengangguran sebesar 0,020060\%.

3. Pertumbuhan ekonomi berpengaruh negatif dan signifikan terhadap tingkat pengangguran di sumatera utara tahun 1978-2014 yaitu ketika pertumbuhan ekonomi 
mengalami kenaikan 1\% maka akan menyebabkan menurunnya tingkat pengangguran sebesar 3,105293\%.

4. Upah minimum berpengaruh negatif dan signifikan terhadap tingkat pengangguran di sumatera utara tahun 1978-2014 yaitu ketika upah minimum mengalami kenaikan $1 \%$ maka akan menyebabkan menurunnya tingkat pengangguran sebesar 1,003877\%.

5. Pendidikan berpengaruh positif dan signifikan terhadap tingkat pengangguran di Sumatera utara tahun 1978-2014 yaitu ketika tingkat pendidikan mengalami kenaikan $1 \%$ maka akan menyebabkan kenaikan tingkat penganguran sebesar $0,282733 \%$.

6. Jumlah angkatan kerja, inflasi, pertumbuhan ekonomi, upah minimum dan tingkat pendidikan secara bersama-sama berpengaruh signifikan terhadap tingkat pengangguran di Provinsi sumatera utara pada tahun 1978-2014.

7. Faktor yang paling dominan mempengaruhi tingkat pengangguran di provinsi sumatera utara tahun 1978-2014 dalam penelitian ini adalah faktor pertumbuhan ekonomi.

\section{Saran}

Berdasarkan kesimpulan dari hasil penelitian diatas, maka diajukan beberapa saran yaitu sebagai berikut :

1. Pemerintah harus membuat sebuah kebijakan dan mengambil peranan yang cukup besar untuk dapat mendorong pencapaian pertumbuhan ekonomi yang lebih maju dengan menaikkan kapasitas produksi masyarakat agar mengurangi tingkat pengangguran di provinsi sumatera utara dan mampu membuka lapangan pekerjaan guna menyerap jumlah tenaga kerja yang dapat membantu masyarakat dalam memenuhi kebutuhan hidup mereka.

2. Bagi peneliti selanjutnya, dapat menambahkan variabel independen yang menjelaskan faktor-faktor yang mempengaruhi tingkat pengangguran di Provinsi Sumatera Utara.

\section{DAFTAR PUSTAKA}

[1] Todaro, M. P., (2000): Pembangunan Ekonomi Jilid 2.di Dunia Ketiga Edisi Ketujuh, Terjemahan oleh Harris Munandar, Penerbit Erlangga, Jakarta. 
[2] BPS (2004): Sumatera Utara Dalam Angka, BPS, Sumatera Utara.

[3] BPS (2014): Sumatera Utara Dalam Angka, BPS, Sumatera Utara.

[4] Dornbusch, Rudiger, d., (2008): Macroeconomics Tenth Edition, The McGraw Hill International Edition, New York.

[5] Nanga, M., (2001): Makroekonomi: Teori, Masalah dan Kebijakan, PT Raja Grafindo Persada, Jakarta.

[6] Samuelson, N., (2003): Ilmu Makroekonomi, PT. Gramedia Global Edukasi, Jakarta

[7] Cita, E., (2014): Analisis Pengaruh Inflasi dan Pertumbuhan Ekonomi Terhadap Pengangguran di Kota Ambon, Jurnal Ekonomi, VIII(1).

[8] Febiana Putri, R., (2015): Analisis Inflasi, Pertumbuhan Ekonomi dan Upah Terhadap Pengangguran Terdidik di Provinsi Jawa Tengah Tahun 2009-2013, Economics Development Analisis Journal, 4(2).

[9] Gujarati, D. N., (2007): Basic Econometrics Fourth Edition, The McGraw - Hill International Edition, New York

[10] Wing, W. W., (2015): Analisis Ekonometrika dan Statistika dengan Eviews edisi 4, Unit Penerbit dan Percetakan, Yogyakarta

[11] Imarotus, H., (2013): Pengaruh Tingkat Pendidikan Terhadap Tingkat Pengangguran di Kabupaten Jombang, Jurnal Fakultas Ekonomi UNESA, .

\section{${ }^{1}$ Isnayanti \\ ${ }^{2}$ Arnah ritonga}

